\title{
Syria and its regional neighbors: A case of cultural property protection policy failure?
}

\section{Neil Brodie}

Scottish Centre for Crime and Justice Research

University of Glasgow

Ivy Lodge

63 Gibson Street

Glasgow

G12 8LR

$\underline{\text { neil.brodie@glasgow.ac.uk }}$

Abstract: Cultural property protection policy as implemented in Syria since 2011 is structured around standards and practices enshrined within the 1954 Hague Convention for the Protection of Cultural Property in the Event of Armed Conflict (including its First and Second Protocols) and the 1970 UNESCO Convention on the Means of Prohibiting and Preventing the Illicit Import, Export and Transfer of Ownership of Cultural Property. Policy emphasis is on the in situ protection of cultural sites and the recovery and return of stolen or looted cultural objects. But policy initiatives have very obviously failed to stop the plunder and illegal trade of cultural objects in Syria, as they have failed before for neighboring countries. This paper describes why policy initiatives aimed at site protection and object recovery have failed and how policy might be improved by a market reduction approach aimed at subduing demand. 


\section{INTRODUCTION}

Insofar as it applies to the illegal trade in antiquities and other cultural objects, international "cultural property protection" policy is structured around two conventions: the 1954 Hague Convention for the Protection of Cultural Property in the Event of Armed Conflict (including its First and Second Protocols), and the 1970 UNESCO Convention on the Means of Prohibiting and Preventing the Illicit Import, Export and Transfer of Ownership of Cultural Property. From principles and recommendations enshrined within these two conventions (and also the 1995 Unidroit Convention on Stolen or Illegally Exported Cultural Objects), the policy aims at cultural site protection at source (broadly defined to include physical protection and the necessary infrastructural support) and the recovery and return of stolen or otherwise illegally-traded cultural objects ${ }^{1}$. Henceforth, this policy will be characterized summarily as one of "protection and recovery". The nature of this policy reflects concerns current in the 1950s and 1960s among newly decolonized countries eager to exert sovereign control over their national cultural heritages and to recover cultural objects removed from their territories while subject to colonial rule. The latter aspiration, to recover objects removed in colonial times, was frustrated by ex-colonial nations wanting to retain possession ${ }^{2}$, but the principle of recovery was secured for material traded illegally after the date of accession to the 1970 UNESCO convention by countries concerned.

\footnotetext{
${ }^{1}$ For more detailed description see Hladik 2013, 17; Manacorda 2011, 17, 40-41; Planche 2013; Prott 2011.

2 Prott 2011.
} 
The widespread looting of archaeological sites in Syria, forty years into this policy regime of protection and recovery, suggests that it has fallen short of its desired objective. It has failed. This paper sets out four reasons for this apparent failure of cultural property protection policy. It discusses possible ways in which policy might be improved by a more pragmatic approach aimed at subduing demand and reducing the volume of the destination market.

\section{PROTECTION AND RECOVERY POLICY AND ITS SHORTCOMINGS}

The March 2011 onset of civil unrest and later armed conflict in Syria was accompanied by an upsurge of reporting in conventional and social media of damage being inflicted upon cultural heritage ${ }^{3}$. Archaeological sites, museums, historical monuments and religious buildings were being damaged intentionally and unintentionally by military action, ideologically-motivated attacks, commercially-inspired theft and looting, and unauthorized construction works. Looted material was reported passing out of Syria into Lebanon ${ }^{4}$, Jordan ${ }^{5}$ and Turkey6. UNESCO responded by organizing a series of regional workshops and

\footnotetext{
${ }^{3}$ For good summaries, see Cunliffe 2012; Ali 2013; DGAM 2014.

${ }^{4}$ Baker, Aryn and Majdal Anjar, "Syria's Looted Past: How Ancient Artifacts are being Traded for Guns." Time, 12 September 2012, http://world.time.com/2012/09/12/syrias-looted-past-how-ancient-artifactsare-being-traded-for-guns/ (accessed 26 September 2014); Jaber, Hala and George Arbuthnott, "Syrians Loot Roman Treasures to Buy Guns." Sunday Times, 5 May 2013; Van Tets, Fernande, "The Art of Civil War." Foreign Policy, 8 May 2013, http://www.foreignpolicy.com/articles/2013/05/08/syrian rebels stolen treas ures art theft guns (accessed 28 September 2013).

${ }^{5}$ Luck, Taylor, "Syrian Rebels Loot Artifacts to Raise Money for Fight Against Assad." Washington Post, 13 February 2013.

${ }^{6}$ Almuquad, Omar, "Syrian Heritage Under Extreme Attack." Global Arab Network, 20 June 2013, http://www.english.globalarabnetwork.com/2013062013174/Culture/syrianheritage-under-extreme-attack.html (accessed 26 September 2014); Mabillard,
} 
expert meetings in Amman (10-13 February 2013), Damascus (12-13 May 2013) and Paris (29 August 2013). One of the main aims of the Amman meeting was to develop an action plan in line with the policy of protection and recovery that would “... protect museums and archaeological sites from looting, prevent illicit trafficking, improve restitutions to Syria ..."7. To achieve these aims, a comprehensive program of action was agreed setting out a series of operational goals. It called for Syrian ratification of the 1999 Second Protocol to the 1954 Hague Convention and of the 1995 Unidroit Convention, improved site protection through awareness raising and capacity building in Syria and neighboring and other countries, and UNESCO-backed mediations with neighboring and other countries for the return of Syrian objects, making full use of the INTERPOL stolen art database ${ }^{8}$.

The UNESCO action plan was implemented on 1 March 2014 as the Emergency Safeguarding of the Syrian Heritage Project (ESSHP), supported for three years by $\$ 2.46$ million of European Union (EU) funding. A “three-pronged” approach was envisaged, realized through the establishment of an International Observatory of Syrian Cultural Heritage, and calling for the monitoring and

Boris, "Snapshot of a Syrian Smuggler: Arms, Antiquities and Jihad Along Turkey's Border." Le Temps, 31 August 2013, http://www.worldcrunch.com/syria-crisis/snapshot-of-a-syrian-smugglerarms-antiquities-and-jihad-along-turkey-039-s-border/syria-smuggling-bordertraffic-jihadists/c13s13205/\#.VChN-edfkyI (accessed 28 September 2014). ${ }^{7}$ Author's italics; Regional Training on Syrian Cultural Heritage: Addressing the Issue of Illicit Trafficking. Amman: UNESCO, 2013, 4, http://www.unesco.org/new/fileadmin/MULTIMEDIA/FIELD/Amman/pdf/201 30322 Report Syria workshop FINAL 01.pdf (accessed 17 October 2014). ${ }^{8}$ Regional Training on Syrian Cultural Heritage: Addressing the Issue of Illicit Trafficking. Amman: UNESCO, 2013,15-18, http://www.unesco.org/new/fileadmin/MULTIMEDIA/FIELD/Amman/pdf/201 30322 Report Syria workshop FINAL 01.pdf (accessed 17 October 2014). 
assessment of damage and destruction at source, national and international awareness raising, and improved protection at source through capacity building including technical support and training for police and heritage professionals in Syria and neighboring countries 9 . ESSHP had been pre-empted in September 2013 by the International Council of Museums (ICOM) Emergency Red List of Syrian Cultural Objects at Risk ${ }^{10}$ and in December 2013 by EU Council Regulation No 1332/2013, which imposed limited trade controls on Syrian cultural objects. In August 2014, the American Schools of Oriental Research (ASOR) launched a project aimed at documenting damage to cultural sites and developing mitigation and preservation projects ${ }^{11}$. Finally, in February 2015, United Nations Security Council Resolution (UNSCR) 2199 placed limited trade controls on Syrian cultural objects with a view to securing their safe return to Syria. ESSHP and the associated ICOM, EU, UN and ASOR initiatives were concrete implementations of the policy of protection and recovery, aimed at improving protection at source, interdicting supply to the destination market and recovering illegally-traded objects. But it is questionable as to what extent they have offered or will in the future offer any real protection to Syrian cultural heritage. By 2015, in spite of these initiatives, the situation was worsening, not improving ${ }^{12}$. There are at least

\footnotetext{
${ }^{9}$ UNESCO-EU: Launch of the Emergency Safeguarding of the Syrian Heritage Project. Paris: UNESCO, 2014, http://www.unesco.org/new/en/safeguardingsyrian-cultural-heritage/international-initiatives/emergency-safeguarding-ofsyria-heritage/ (accessed 17 October 2014).

${ }^{10}$ Emergency Red List of Syrian Cultural Objects at Risk. Paris: ICOM, 2013. http://icom.museum/fileadmin/user upload/images/Redlists/Syria/ERL SYRIE EN.pdf (accessed 16 October 2014).

${ }^{11}$ ASOR Syrian Heritage Initiative http://www.asor-syrianheritage.org/ (accessed 17 October 2014).

${ }^{12} \mathrm{Al}-\mathrm{Azm}, \mathrm{Amr}$, "The Pillaging of Syria's Cultural Heritage." Middle East Institute, 22 May 2015, http://www.mei.edu/content/at/pillaging-syrias-culturalheritage? (accessed 30 May 2015).
} 
four very practical reasons why they have failed for Syria and are likely to fail for other countries around the world. The reasons are (1) the emphasis of policy initiatives on cultural site protection at source, (2) the reactive nature of policy initiatives, (3) the targeting of policy initiatives at single countries, and (4) the emphasis of policy initiatives on securing the recovery and return of stolen and looted objects. In what follows, each of these reasons will be examined in more detail.

\section{Protection at source}

The policy emphasis on protection at source, with protection conceived holistically to include public awareness and improved capacity alongside actual physical in situ protection, is unrealistic. To what extent these measures can ever offer long-term, comprehensive protection to cultural sites is questionable because of the demands they place on available resources. It has long been recognized that no country has the resources necessary to protect its cultural heritage from the attention of determined thieves ${ }^{13}$. In Syria there are an estimated 10,000 archaeological sites, and even before the current conflict it was only possible to employ something like one guard for every five sites ${ }^{14}$. A similar situation prevailed in peacetime Iraq ${ }^{15}$. The fall-back option is to concentrate resources on a small number of "significant" sites, presumably abandoning the rest to depredation. In any event, protection dissipates when it is needed most during periods of civil disorder, conflict, or economic recession or collapse.

\footnotetext{
13 Brodie 2002, 17-18.

14 Ali 2013, 352.

15 Russell 2008, 31.
} 
The example of Iraq is a cogent one. John Russell, who was Deputy Senior Advisor for Culture for the Coalition Provisional Authority in Iraq from September 2003 until 2004, has described the financial and material support provided by governments and private foundations for active site protection on the ground in Iraq, where sites had been heavily looted since the 1990s. He states that because of the large number of archaeological sites needing protection from looters, the efforts of first the Italian Comando Carabinieri Tutela Patrimonio Culturale and later the Iraqi Archaeological Site Protection Force were by necessity focused on protecting only the largest ones ${ }^{16}$. The early signs were that this injection of money, material and expertise had gone some way towards bringing the situation under control, but by 2008 there were reports of an upturn of looting in some areas ${ }^{17}$. Although a 2008 British inspection in southern Iraq of eight important sites found no evidence of recent looting (it could not comment on the situation at smaller sites) ${ }^{18}$, Russell concluded the same year that despite the human and physical resources committed to site protection, looting was still not under control and that there were long term problems of sustainability ${ }^{19}$. Lawrence Rothfield offered a similar pessimistic assessment ${ }^{20}$. Using satellite imagery, Katharyn Hanson showed that at the site of Umma in south Iraq, one of the large sites that was offered some protection, 8318 looters pits were dug between 2003 and June 2005, dropping to 500 between June 2005 and June 200821. No evidence has

\footnotetext{
16 Russell 2008, 34-41.

17 Russell 2008, 41-42.

18 Curtis et al. 2008.

19 Russell 2008, 42.

${ }^{20}$ Rothfield 2009, 136-48.

${ }^{21}$ Hanson 2011, 117-119.
} 
been forthcoming for the situation at smaller sites. In 2009, archaeologist McGuire Gibson, who has worked extensively in Iraq, stated that "... looting on a scale that involves virtual destruction of whole cities ... is still occurring in southern Iraq, and there is no prospect of its ending"22. Thus at best the improved site protection ameliorated but did not solve the problem, though it is equally and perhaps more likely that any mitigation was due more to the restoration of effective civil government and consequent improvements in public order and legitimate economy. Furthermore, it seems likely that some material assistance was diverted away from heritage protection by agencies unknown ${ }^{23}$, at worst to fund militia groups but more likely for the personal gain of corrupt individuals and so acting as a drag on civic reconstruction. It that was the case, material assistance for in situ protection of cultural heritage would have been worse than useless.

The political and military fragmentation of Syria has not permitted direct in situ material assistance of the type that was possible in Iraq. Nevertheless, policy interventions have still been source directed. On 20 May 2015 UNESCO released an infographic on the first year's activities of ESSHP. It reported damage documentation, communication and awareness-raising, and technical assistance and capacity building in Syria and neighboring countries ${ }^{24}$. There was no mention of any actions aimed at subduing demand or tackling the destination

\footnotetext{
22 Gibson 2009, 197.

${ }^{23}$ Rothfield 2009, 148; Kimmelman, Michael, "Struggle to Secure Iraq's Shared Past, and Perhaps its Future." New York Times, 9 April 2015.

${ }^{24}$ Emergency Safeguarding of the Syrian Cultural Heritage. Activities Undertaken During the First Year of the Project. Paris: UNESCO, 2015, http://www.unesco.org/new/fileadmin/MULTIMEDIA/HQ/CLT/pdf/UNESCO S afeguarding Syrian Cultural Heritage.pdf (accessed 20 May 2015).
} 
market. Similarly, the ASOR Syrian Heritage Initiative claimed to implement "cultural property protection" by documenting damage done to Syrian cultural heritage, promoting global awareness, and planning emergency and post-war reconstruction ${ }^{25}$. Again, however, the focus was very much on source.

The Iraq experience was presented in a positive light at the February 2013 UNESCO meeting in Amman ${ }^{26}$, but five months earlier in October 2012 a UNESCO roundtable had been convened to discuss the challenges and achievements of protecting Iraq's cultural heritage because:

There remain however enormous needs in terms of strategic planning, infrastructure development for sites and museums, efficient protection of sites, excavation campaigns, restoration and conservation, international cooperation particularly in the area of restitution of stolen or illicitly exported cultural property ... $^{27}$

This was an implicit admission that ten years of protection and recovery policy initiatives aimed at safeguarding sites in Iraq had not served to bring the problem under control. As the italicized wording shows, the solution offered was for more of the same. The same solution was offered for Syria, though with the same poor prospect of success.

${ }^{25}$ ASOR Syrian Heritage Initiative http://www.asor-syrianheritage.org/ (accessed 17 October 2014).

${ }^{26}$ Regional Training on Syrian Cultural Heritage: Addressing the Issue of Illicit Trafficking. Amman: UNESCO, 2013, 10-11, http://www.unesco.org/new/fileadmin/MULTIMEDIA/FIELD/Amman/pdf/201 30322 Report Syria workshop FINAL 01.pdf (accessed 17 October 2014).

${ }^{27}$ Author's italics; Safeguarding Iraqi Archaeological Heritage: Current Challenges and Achievements. Paris: UNESCO, 2012, http://www.unesco.org/new/fileadmin/MULTIMEDIA/HQ/CLT/pdf/Round Ta ble on Iraq Archaeological Heritage Eng .pdf (accessed 17 October 2014). 


\section{Reactive policy interventions}

In practice, if not in conception, the policy of protection and recovery is reactive. Reactive policy interventions fail for two reasons. First, they provide time and space for the unimpeded development of smuggling routes and a functioning market. Second, they come too late to prevent serious damage. It was well known that Syrian archaeological sites were being looted in the 1990s and 2000s ${ }^{28}$ and that Syrian cultural objects were being illegally traded. Nevertheless, although the trade had prompted new Syrian legislation in $1999^{29}$, no international action was taken at that time to stop it. Satellite imagery of archaeological sites confirms that looting was already established before the 2011 onset of fighting ${ }^{30}$. One study of five sites for which images are available from before and after 2011 identified evidence of pre-2011 looting on every site, sometimes on a large scale $^{31}$. At Dura Europas, for example, "hundreds or possibly thousands of looting holes" were counted on an image dating to 200732. The Syrian director of museums Hiba al-Sakhel was quoted as saying in 2012 that the looting of archaeological sites had been ongoing for many years, but had accelerated as sites had been left unprotected during the fighting 33 . She was right. Organized smuggling networks established unhindered during the 1990s and 2000s were already in place and in a position to take advantage when fighting broke out and

\footnotetext{
28 Cunliffe 2012, 18-19; DGAM 2014, 8.

${ }^{29}$ Abdulrahman 2001.

30 Cunliffe 2012, 18, 20; Casana and Panahipour 2014.

31 Casana and Panahipour 2014, 148, table 1.

32 Casana and Panahipour 2014, 143.

33 Zablit, Jocelyne, "Looters tear up Syria's archaeological treasures". Daily Star, 6 April 2012, http://www.dailystar.com.lb/Culture/Art/2012/Apr-06/169378experts-sound-alarm-over-syria-archaeological-treasures.ashx\#axzz3EdLrSopz (accessed 28 September 2014).
} 
looting moved up a gear in 2011. The existence of these networks was suspected at least by Syrian authorities. A memo prepared by the Syrian prime minister Adel Safar in July 2011 warned of groups of criminals specialized in the theft of antiquities and manuscripts preparing to enter Syria ${ }^{34}$.

Even when it became clear post-2011 that cultural sites in Syria were being damaged or destroyed it was a further two years before the international community began to organize a response. ICOM was first to act, but even then did not release its Emergency Red List of Syrian Cultural Objects at Risk until September 2013, more than two years after the outbreak of fighting and ten years after the start of serious looting. As noted above, international support for capacity building aimed at enhancing site protection did not start reaching Syria until March 2014 with the establishment of the EU-funded ESSHP. The EU trade controls implemented in December 2013 do not apply to material exported from Syria before 9 May 2011, even though under the 1999 (amending 1963) Syrian national antiquities law, "movable" antiquities are state property and their export abroad for sale is forbidden ${ }^{35}$. Similarly, the trade controls implemented by UNSCR 2199 of February 2015 do not apply to material taken out of Syria on or before 15 March 2011.

These reactive interventions have failed to prevent the large scale looting of archaeological sites in Syria. A similar story of delayed and fragmented response to a crisis-inspired "emergency" could be repeated for Iraq, hinging on the March 2003 Coalition invasion and subsequent looting of the National Museum in

${ }^{34}$ Cunliffe 2012, 13-14.

35 Abdulrahman 2001. 
Baghdad, years after serious looting had started in the 1990s. Again, international help arrived too late to prevent the calamitous looting of Iraqi museums and archaeological sites.

\section{Country-specific policy interventions}

The policy of protection and recovery is country-specific. The policy is not intended to be country-specific, but over the past three decades it has structured what are now termed "emergency actions" as the cultural heritage of one country after another has come under threat during a period of armed conflict. Country-specific emergency actions fail for two reasons. First, the targeting of international assistance at cultural heritage protection in one country leaves the cultural heritage of other countries vulnerable. Second, country-specific trade controls such as those imposed by UNSCRs take no account of the facts that both archaeological cultures and smuggling operations can spread across the territories of more than one modern country.

Already in 2001, Andrew Lawler had identified the problem with emergency country-specific actions when he wrote in Science about Iraq that an "extensive crisis has been unfolding for the past decade with barely a murmur of protest from the international community"36. Lawler was complaining about the lack of any concerted action aimed at stemming the illegal flow out of Iraq and onto the international market of Iraqi artifacts while public and political attention was focused on Afghanistan after the 1993 looting of the National Museum in Kabul and more looting and destruction around the country, culminating the 2001

${ }^{36}$ Lawler 2001, 32. 
demolition of the Bamiyan Buddhas ${ }^{37}$. Yet it was during the late 1990s that a vigorous market in Iraqi antiquities developed despite what on paper was a draconian regime of UN trade sanctions imposed by UNSCR 661 in August 199038. Between 1991-2003, UNSCR 661 was largely ignored and large collections of Iraqi artifacts were assembled in Europe and North America39. Yet, as Lawler correctly noted, not much was done about it.

The situation changed radically in 2003 when the Coalition invasion of Iraq triggered a new wave of looting and destruction, and a new "emergency" situation unfolded, attracting media and political attention and triggering the policy response aimed at site protection described above. By 2008, it was easy to predict that the shift of international attention and resources to Iraq would leave the cultural heritage of other countries open to the depredations of the market ${ }^{40}$. Syria, for one, was offered no assistance during this period of what can now in retrospect be seen to have been one of growing vulnerability for its cultural heritage. Thus whatever the merits or otherwise of policy implementations during the late 2000s aimed at protecting Iraqi heritage, in one conspicuous respect, they failed - the financial, material and human resources committed to Iraq did nothing to secure protection for Syrian heritage. Meanwhile, in the wider region, archaeological sites were being looted in other countries too. The problem had reached crisis proportions in Jordan by the $1990 \mathrm{~s}^{41}$, but the country

\footnotetext{
37 Grissman 2006.

38 Russell 2008, 31; Brodie 2006; Gibson 2009.

39 Brodie 2011.

40 Brodie 2008, 72.

41 Politis 2002; Bisheh 2001, Rose and Rose 2004; Contreras and Brodie 2010; Brodie and Contreras 2012; Kersel and Chesson 2013.
} 
was never offered the international attention or support afforded to Iraq and Syria.

To some extent, it might be possible to characterize the looting in Syria and Jordan during the 1990s and 2000s as "spillover" from events in Iraq. Jordan was plunged into economic recession by the 1991 Gulf War, which encouraged people to engage in illegal digging and trading ${ }^{42}$. The spillover might also have manifest through the emergence of regional smuggling networks, perhaps centered on Iraq and drawing impetus from the political and economic fallout of the 1991 and 2003 wars but extending throughout the wider region. By and large, collectors and dealers do not specialize according to country. Throughout the 1990s, for example, there were persistent allegations of a trading network orchestrated by Amman resident Ghassan Rihani, which was transporting material from Iraq and Jordan but also - not remarked upon at the time - Syria for sale in London and beyond ${ }^{43}$. Rihani died in 2001, without any serious effort having been made to investigate his business organization and practices, but the international origins of his traded material are noteworthy. When faced by trading networks are that are transnational in their organization and reach, a country-specific policy response is clearly inappropriate.

The country-specific approach also falls foul of the fact that archaeological cultures are often not coincident with modern national borders. Many objects of

\footnotetext{
42 Bisheh 2001, 115.

43 Gottleib, Martin and Barry Meyer, "Of 2,000 Treasures Stolen in Gulf War of 1991, only 12 have been Recovered." New York Times, 1 May 2003, http://www.nytimes.com/2003/05/01/world/aftereffects-plunder-2000treasures-stolen-gulf-war-1991-only-12-have-been.html (accessed 28 September 2014); Brodie and Kersel 2014, 206-208.
} 
types shown on the ICOM Red List of Syrian Cultural Objects, for example, can also be found in neighboring countries. Thus a system of "emergency" trade control such as those of the EU and UN aimed only at Syrian objects, or even at Iraqi and Syrian objects, still leaves wide open the opportunity for material to be sold and collected with impunity as originating in Turkey, or Jordan, or Lebanon, or another country in the region. Rihani, for example, was able to ignore UNSCR 661 by claiming a Jordanian origin for material he was trading from Iraq ${ }^{44}$.

The international community did nothing to stop the trade in Syrian objects during the 1990s and 2000s because its attention was focused on the situation on Iraq. Once attention had shifted to Syria, Iraq was seemingly forgotten. Until July 2014, that is, when in response to news reports of a new wave of destruction and illegal trade at the hands of the Islamic State of Iraq and Syria (ISIS), UNESCO introduced another "emergency response action plan" to protect cultural heritage in Iraq, again calling for improvements in inventory and training and international ratification of the relevant conventions ${ }^{45}$. So, by August 2014, there were two separate emergency action plans, one aimed at Syria, the other at Iraq. Meanwhile, in neighboring Lebanon, the illegal export of antiquities was ongoing, in Yemen too, the situation was serious, and in Jordan, Egypt and perhaps Iran and Turkey. The list of countries could go on. In February 2015, Laura Mallonnee

\footnotetext{
${ }^{44}$ Freeman et al 2005, 8-18.

45 UNESCO-EU: Launch of the Emergency Safeguarding of the Syrian Heritage Project. Paris: UNESCO, 2014, http://www.unesco.org/new/en/safeguardingsyrian-cultural-heritage/international-initiatives/emergency-safeguarding-ofsyria-heritage/ (accessed 17 October 2014).
} 
asked "Why is no one talking about Libya's cultural destruction?" 46 . She was right to ask. The answer was that the attention of the international community were very firmly focused on the actions of ISIS in Iraq and Syria

\section{Recovery and return}

The practice of securing the recovery and return of objects stolen from museums, libraries and archives is understandable. But more generally, the practice is of limited utility. It does not restore damage caused by the looting of archaeological sites, nor does it deter dealers from trading in illegally-acquired material. The emphasis on recovery and return of a policy that is used if not intentionally designed to protect the archaeological contexts of archaeological objects is dubious. By the time an object is subject to recovery, its informational value has been lessened, perhaps irredeemably so, by the destruction of context caused by its theft, clandestine excavation and illegal trade. It is easy to understand the rationale for the recovery of important pieces such as the Euphronios krater, for example. Even out of their original contexts, they are considered to be significant works of ancient art. But most archaeological objects on the market are not of that standard. The occasional seizure and return of small numbers of cuneiform tablets looted from Iraq, for example, during a time when collections numbering in their thousands were being assembled in Europe and North America ${ }^{47}$, cannot have mitigated the loss caused to historical knowledge by past looting. Thus the return of small numbers of relatively

46 Mallonnee, Laura, "Why is No One Talking about Libya's Cultural Destruction?" Hyperallergic, 2 February 2015, http://hyperallergic.com/179246/why-is-noone-talking-about-libyas-cultural-destruction/ (accessed 10 February 2015). 47 Brodie 2011. 
mundane objects does not and cannot repair the cultural harm caused the damaging circumstances of their removal. Worse, it imposes an unforeseen and unasked for cost on the country concerned in terms of long-term curation.

Unfortunately, in accordance with the policy of protection and recovery, law enforcement and particularly customs authorities are encouraged to recover and return these archaeologically unimportant objects without following through with criminal prosecution. In 2009, for example, the UK returned to Afghanistan more than 1500 artifacts weighing together 3.4 tons. The material had been seized by UK customs during random searches made since 2003 at London's Heathrow airport of incoming passengers from Pakistan and the United Arab Emirates. All the objects had been illegally traded, but it was reported that something like 90 per cent were of limited importance because of their lost contexts $^{48}$. A second shipment of 800 objects was returned in $2012^{49}$. The fact that more than 2000 objects were discovered in the luggage of incoming air passengers suggests a substantial number of individual interceptions of people passing through customs, but it is noticeable that no prosecutions or convictions were ever reported. Presumably recovery and return were considered an appropriate and sufficient response.

\footnotetext{
${ }^{48}$ Peters, Gretchen. "More than 1,500 Stolen Afghan Artifacts Return to Kabul." National Geographic, 6 March 2009, http://news.nationalgeographic.com/news/2009/03/090306-afghanistanartifacts-returned-missions.html (accessed 16 October 2014). ${ }^{49}$ Farmer, Ben, "Afghan Treasures Repatriated." Daily Telegraph, 5 August 2012, http://www.telegraph.co.uk/news/worldnews/asia/afghanistan/9453685/Afg han-treasures-repatriated.html (accessed 27 September 2014).
} 
This pattern of seizure and civil forfeiture without prosecution is widespread.

Between 1991 and 1998, Canadian customs seized 76 pieces of floor mosaic declared as Lebanese handicrafts but in fact illegally-exported from Syria. Expert analysis suggested the pieces had come from western Syria, probably from somewhere close to the town of Hama ${ }^{50}$. All were returned to the ownership of Syria in 1999. A Canadian customs officer was quoted at the time as saying there had been no arrests as it was simpler to proceed under civil law ${ }^{51}$. Presumably, the criminals involved were left free to continue their wrongdoing, and perhaps to trade Syrian objects looted after 2011. And the criminals involved might have been frightening. The mosaics must have been looted in the late 1980s, at a time when Shabiha criminal gangs were heavily involved in smuggling cultural objects out of Syria ${ }^{52}$. The Shabiha subsequently took to the field in 2011 as a violent pro-Assad militia. During the early 1980s, until his fall from favor in 1985, the antiquities trade in Syria was controlled by Rifaat al-Assad (uncle of Bashar alAssad). In 2007 it was alleged that he was the one who "stole Hamah antiquities" 53 . The Canadian archaeologist involved in returning the mosaics to Syria expressed concern about the indifferent attitude of his Syrian

\footnotetext{
50 Fossey 2015, 209.

51 Reuters. "Canada Returns Smuggled Ancient Mosaics to Syria." Reuters, 20 April 1999, http://cnn.com:80/WORLD/americas/9 ... 0/canada.artifacts.reut/index.html (accessed 21 April 1999).

52 Al-Haj Salih, Yassin. "The Syrian Shabiha and their State - Statehood and Participation", Heinrich Böll Stiftung, 3 March 2015, http://lb.boell.org/en/2014/03/03/syrian-shabiha-and-their-state-statehoodparticipation (accessed 12 March 2015).

53 "Saudi king prays with Rif'at al-Asad in Mecca." Quds Press News Agency, 12 October 2007, http://www.joshualandis.com/blog/saudi-king-prays-with-rifatal-asad-in-mecca/ (accessed 12 March 2015).
} 
counterparts ${ }^{54}$. Their seemingly reluctant cooperation might be more understandable in the threatening context of Shabiha profit and violence.

For another example, between 2008 and 2011 there were two seizures by US customs and one by UK customs of objects coming from Iraq, Egypt and Libya, all dispatched by the same Dubai-based dealer Hassan Fazeli and all with associated documents listing Turkey as country of origin. In 2008 US customs intercepted an Assyrian stone head from Iraq ${ }^{55}$ and in 2010 a shipment at Newark International Airport, this time comprising five ancient Egyptian artifacts ${ }^{56}$. The Assyrian head was returned to Iraq in March $2015^{57}$ and the Egyptian pieces returned to Egypt in April 201558. In 2011, half a marble statue believed to have been looted from Cyrene in Libya entered the UK and was seized by UK customs two years later in 2013 from a bonded warehouse at Heathrow Airport ${ }^{59}$. No further investigations have been announced into the ongoing dealings of Fazeli

\footnotetext{
54 Fossey 2014, 211.

${ }^{55}$ St. Hilaire, Rick, "Seized Assyrian Head Named in Forfeiture Complaint Smuggling Allegations Raised." Cultural Heritage Lawyer, 24 July 2013, http://culturalheritagelawyer.blogspot.co.uk/2013 0701 archive.html (accessed 16 October 2014).

${ }^{56}$ Scott, Lucile, "Uncle Sam Seizes Ancient Egyptian Art." Courthouse News Service, 22 March 2013, http://www.courthousenews.com/2013/03/22/55962.htm (accessed 16 October 2014).

${ }^{57}$ Ancient Antiquities and Saddam Hussein-era objects returned to Iraq. 16 March 2015a, http://www.ice.gov/news/releases/ancient-antiquities-andsaddam-hussein-era-objects-returned-iraq (accessed 19 May 2015).

${ }^{58}$ ICE Returns Ancient Artifacts to Egypt at National Geographic Society. 22 April 2015b, http://www.ice.gov/news/releases/ice-returns-ancient-artifacts-egyptnational-geographic-society (accessed 19 May 2015).

${ }^{59}$ Ward, Victoria, "Court Sits at British Museum for First Time as Judge Studies Looted Libyan Sculpture". Telegraph, 30 March 2015.
} 
who is presumably free to carry on trading material from Iraq, Egypt, Libya and potentially - Syria and other countries in the region.

Seizures and forfeiture actions are defended because the lower burden of proof and reduced mental requirement of civil actions makes it easier to recover objects than would otherwise be the case through criminal prosecution ${ }^{60}$. But if they are intended to exert a deterrent effect upon dealers, it is far from clear that they do. They are not likely to discourage further illegal trading because of the mark-ups in price that occur as material enters the destination market ${ }^{61}$. In the Fazeli cases, for example, the Assyrian head had a declared import value of $\$ 6,500$ and an appraised market value of $\$ 1,200,000^{62}$. The five Egyptian pieces together had a declared import value of $\$ 17,000$ and an appraised market value of $\$ 57,000^{63}$. The Libyan statue had a declared import value of $£ 60,000$ but was estimated to be worth at least $£ 1.5$ million ${ }^{64}$. Even for the lower priced Egyptian pieces, if the importer was forced to bear the financial loss of the forfeiture, it could be written off by the subsequent sale of one successfully received shipment. Thus financial losses incurred through seizures and civil forfeitures are not so much a deterrent as a cost of doing business that can be factored into

60 Gerstenblith 2009, 315; Prott 2011, 7

61 Gerstenblith 2009, 315

${ }^{62}$ St. Hilaire, Rick, "Seized Assyrian Head Named in Forfeiture Complaint Smuggling Allegations Raised." Cultural Heritage Lawyer, 24 July 2013, http://culturalheritagelawyer.blogspot.co.uk/2013 0701 archive.html (accessed 16 October 2014). ${ }^{63}$ St. Hilaire, Rick, "Seized Assyrian Head Named in Forfeiture Complaint Smuggling Allegations Raised." Cultural Heritage Lawyer, 24 July 2013, http://culturalheritagelawyer.blogspot.co.uk/2013 0701 archive.html (accessed 16 October 2014).

${ }^{64}$ Ward, Victoria, "Court Sits at British Museum for First Time as Judge Studies Looted Libyan Sculpture". Telegraph, 30 March 2015. 
the pricing arrangement. Rick St. Hilaire ${ }^{65}$ has additionally pointed out that seized objects are potentially material evidence of criminal wrongdoing, so that their return to country of origin effectively precludes any criminal proceedings against alleged wrongdoers.

\section{PRAGMATIC POLICY OPTIONS}

For the four reasons described, the UNESCO-inspired policy of protection and recovery as implemented through emergency actions failed to secure the cultural heritage of Syria before or during the armed conflict that broke out in March 2011. For the same reasons, there are no grounds for believing that the policy will be any more successful in the future, either in Syria, in neighboring countries, or indeed anywhere else in the world. The illegal trade in cultural objects is a persistent global problem, and any response aimed at controlling the trade needs to be conceived and implemented globally and applied resolutely and consistently.

In geographical and social terms the trade is organized internationally around some highly localized centers of demand with a more extensive and distributed periphery of supply ${ }^{66}$. Thus common sense would suggest that for effective use of available resources, any policy aimed at controlling the trade should focus on demand and not supply. This supposition seems to be confirmed by the generally unsuccessful attempts to control or eliminate other illegal trades by restricting

\footnotetext{
65 St. Hilaire, Rick, "Seized Assyrian Head Named in Forfeiture Complaint Smuggling Allegations Raised." Cultural Heritage Lawyer, 24 July 2013, http://culturalheritagelawyer.blogspot.co.uk/2013 0701 archive.html (accessed 16 October 2014).

66 Brodie 2014, 33-35.
} 
supply in conditions of high demand ${ }^{67}$. Experts who worked on the ground in Iraq, from their own empirical perspectives, have said much the same thing. John Russell recommended that "A comprehensive site protection solution must address the demand side of the market as well as the supply side"68. Joanne Bajjaly, who experienced the looting in Iraq at first hand, wrote that "The bleeding cannot be stopped from the source, but in the market. The power of this market should be checked and this type of trade should become illegal, not merely in UNESCO charters, but through painful penalties against traders and dealers in the importing countries as well" 69 . These experts concur that the real weakness of the protect and recover policy being criticized here is that it fails to impose proactive and effective constraint on demand as realized in the destination market. What is required is a more pragmatic approach to policy that aims to create a more inhospitable trading environment for the destination market. It must be a policy of possibilities, looking towards individual measures that are tailored to fit different legal, political and socioeconomic realities. It must be responsive to and able to obstruct globalized trading networks that work opportunistically through the interstices of unevenly enforced international laws and regulatory regimes.

Criminological studies of other illegal trades have emphasized the utility of a "market reduction approach" (MRA) for subduing demand ${ }^{70}$. The fundamental

\footnotetext{
67 Polk 2009, 17-18.

68 Russell 2008, 42-43.

${ }^{69}$ Bajjaly, Joanne, "Arms for Antiquities: Syrian Artifact Smuggling Bleeds Sites Dry.” Al Akhbar English, 3 September 2013, http://english.alakhbar.com/content/arms-antiquities-syrian-artifact-smuggling-bleeds-sitesdry (accessed 26 September 2014).

70 Mackenzie and Green 2009, 152-153; Mackenzie 2011, 80-82.
} 
objective of an MRA is to increase the risks involved for all parties engaged in illegal trading. In the present context, this would include all institutions and individuals associated with the transporting, marketing and purchasing of illegally-traded cultural objects, and those facilitating such activities ${ }^{71}$. An MRA is evidence led. It depends for its implementation upon an accurate description of the marketing process, from which it can direct moral, regulatory and law enforcement efforts for maximum effect. An effective MRA makes full use of moral persuasion, guided by codes of professional and ethical conduct, but at its heart there must be a credible mechanism of punitive deterrence ${ }^{72}$.

Moral persuasion is central to any strategy or campaign of cultural heritage protection. The work of ICOM and other museum organizations, for example, in publicizing the problems associated with collecting illegally-traded objects and in encouraging the adoption of rigorous acquisitions policies has been invaluable, as has the indefatigable work of UNESCO in organizing training workshops in many countries around the world. The 1970 UNESCO Convention itself in establishing a set of internationally recognized definitions and standards provides the context, rationale and normative reference for moral persuasion. But too often persuasion in the form of "awareness raising" or "public education" is aimed primarily at source communities, a central plank for example of the Syria and Iraq emergency action plans previously discussed. Even when it is used in destination market contexts, aimed at subduing demand, it can be countered or deflected by better-resourced narratives of justification and denial ${ }^{73}$. These

\footnotetext{
${ }^{71}$ Mackenzie and Green 2009, 152-153.

72 Chappell and Polk 2011, 107-110.

73 Mackenzie 2014.
} 
narratives convince a receptive audience of academics, museum curators and other cultural arbiters that what is in reality a straightforward problem of crime reduction or prevention can be recast as an ethical issue, focusing on the public benefit of the trade, and leaving room for individual choice as regards the propriety of engagement with stolen cultural objects. Opinions that should be expressed legitimately in policy debate about the nature or effectiveness of established law are offered instead as justifications for law evasion. Attempts to persuade the US museums community to adopt more ethically congruent acquisitions policies, for example, fell on deaf ears until several museums were forced by Italy to return material that had been shown to have been stolen. In the end it was these episodes of public shaming that forced the Association of Art Museum Directors (AAMD) in 2004 and 2008 to adopt progressively more stringent guidelines for museum acquisitions of cultural objects, something that moral persuasion had signally failed to achieve.

Thus while moral persuasion might have a role to play in market reduction, it needs to be stiffened by an unambiguous punitive deterrent. A more criminal treatment of the trade is certainly warranted by what is known of its operation. In 2013, for example, a senior Lebanese police officer stated that in Syria armed groups might be digging up antiquities that could be exchanged for weapons and highlighted the corrupt complicity of customs and border forces, whose cooperation could be secured by the payment of bribes or "tariffs" 74 . There are

\footnotetext{
${ }^{74}$ Bajjaly, Joanne. "Arms for Antiquities: Syrian Artifact Smuggling Bleeds Sites Dry." Al Akhbar English, 3 September 2013, http://english.alakhbar.com/content/arms-antiquities-syrian-artifact-smuggling-bleeds-sitesdry (accessed 26 September 2014).
} 
also reports from Syria of ISIS "taxing" the trade 75 , a common feature of economies in areas dominated by organized criminals or "hybrid" criminal/militia groups. The practice has been reported previously in Afghanistan ${ }^{76}$ and presumed in Iraq ${ }^{77}$. There might even be direct links between criminals or armed groups on the ground and money gathering from further afield. In the case of Afghanistan, for example, it has been reported that expatriate traders of cultural objects in Dubai are being forced to pay tax or protection money to ensure the safety of their families back home ${ }^{78}$. Although media attention has focused on the links between cultural object smuggling and weapons procurement or terrorist financing, it has been argued that the worst consequence of organized or hybrid crime in conflict zones such as Syria, Iraq and Afghanistan is corruption, particularly when it infects the police and other institutions of government ${ }^{79}$. Bearing in mind that the monetary profits made from the sale of illegally-traded cultural objects increase progressively and steeply as the objects travel from source to destination, corruption is something that is likely to travel along with them. Thus the known entanglements between the trade and other illegal and harmful activities warrant a stronger criminal justice response than the practice of forfeiture and return provides. A criminal justice solution should focus on crime and the proceeds of crime as much as it does on recovering stolen property. Threatening criminals with serious financial

\footnotetext{
75 Al-Azm, Amr, Al-Kuntar, Salam, and Brian I. Daniels. "ISIS' Antiquities Sideline." New York Times, 2 September 2014.

76 Brodie 2009, 50.

77 Williams 2009, 177.

78 Peters 2010, 36.

79 Peters 2010; Williams 2009, 15.
} 
loss or custodial sentencing will prove a more effective deterrent that the occasional loss through customs seizure.

Arguably, the most effective disruption of the trade was achieved by Italy during the 1990s and $2000 \mathrm{~s}^{80}$. A prolonged campaign of criminal investigation culminating in several convictions broke a long-standing international trading network, recovered a quantity of artistically significant pieces and ultimately forced the AAMD to adopt its stronger acquisitions guidelines. A similar success was registered by the collaborative investigation in India and the US of Manhattan-based dealer Subhash Kapoor. Both of these investigations highlighted the important organizing roles played by a small number of people in sustaining far-ranging smuggling operations that move large quantities of material. Research has unveiled a similar scenario in Cambodia ${ }^{81}$. These findings suggest that a decapitation strategy might work - well-resourced, targeted investigations and prosecutions of the dealers who articulate and control the larger trading networks.

The threat of criminal prosecution should also extend to professional experts such academics, museum curators and conservators whose knowledge and expertise is crucial for establishing the monetary value of illegally-traded cultural objects in private possession, thereby facilitating their acquisition and disposal and thus profit-taking ${ }^{82}$. Similarly, the role of shippers in transporting stolen material might also be questioned. These professionals and other white-

\footnotetext{
80 Watson and Todeschini 2007.

${ }^{81}$ Mackenzie and Davis 2014.

82 Brodie 2011; Ulph and Smith 2012, 109-111.
} 
collar employees often have rewarding and respectable jobs, and although they might be prepared to resist moral persuasion by claiming ethical choice when engaging with stolen cultural objects, they are likely to respond to moral persuasion when persuasion is backed up by a clear and portentous danger of criminal investigation. The risks of job loss and obloquy would cut through the self-serving and obfuscational narratives of justification and denial.

\section{CONCLUSION}

This paper has stated - deliberately, provocatively and polemically - that in Syria and its regional neighbors cultural property protection policy has failed. At this point, however, it is essential to draw back from the statement itself and examine exactly what is intended by its assertion. As already described, the cultural heritage of Syria is threatened by various modalities of destruction - ideological, military and commercial. The arguments adduced for policy shortfall relate only to the latter case - the looting and illegal trade of antiquities and other cultural objects for financial gain. Clearly, for military and ideological threats, the policy imperative is for in situ protection, and the efficacy or otherwise of emergency actions should be considered in that light. Policy responses should be crafted to meet the destructive agencies in play; a "one size fits all" solution does not work. Even as regards only the looting and illegal trade of cultural objects, the policy cannot be said to have failed completely. UNESCO and its associated organizations have worked for decades developing and promoting the normative context of cultural property protection and securing an international consensus for its legitimacy - an essential tool of moral persuasion as already discussed. Nevertheless, at the end of the day, the policy has fallen short, in that it has not 
stopped illegal trade, and the ongoing and worsening looting in Syria and other countries around the world is evidence of that fact. International public policy should move away from country-specific "emergency" implementations of protection and recovery and focus instead on developing long-term, global strategies of market reduction. If the destination market in cultural objects from Syria and its regional neighbors had been tackled decisively in the 1990s, the damage caused by looting since then in Syria and the wider region would have been lessened.

\section{ACKNOWLEDGEMENTS}

A preliminary version of this paper was presented at the Art and Cultural Heritage Law Conference at the University of Geneva's Art Law Centre in June 2014. The work was supported by the European Research Council under the European Union's Seventh Framework Programme (FP7/2007-2013)/European Research Council Grant agreement no. 283873 GTICO.

\section{BIBLIOGRAPHY}

Abdulrahman, Ammar. 2001. "The New Syrian Law on Antiquities." In Trade in Illicit Antiquities: The Destruction of the World's Archaeological Heritage, edited by Neil Brodie, Jennifer Doole, and Colin Renfrew, 111-114. Cambridge: McDonald Institute for Archaeological Research.

Ali, Cheikhmous. 2013. “Syrian Heritage Under Threat.” Journal of Eastern Mediterranean Archaeology and Heritage Studies 1: 351-366. 
Bisheh, Ghazi. 2001. “One Damn Illicit Excavation After Another: the Destruction of the Archaeological Heritage of Jordan." In Trade in Illicit Antiquities: The Destruction of the World's Archaeological Heritage, edited by Neil Brodie, Jennifer Doole, and Colin Renfrew, 115-118. Cambridge: McDonald Institute for Archaeological Research.

Brodie, Neil. 2002. "Introduction." In Illicit Antiquities: the Theft of Culture and the Extinction of Archaeology, edited by Neil Brodie and Kathryn Walker Tubb, 122. London: Routledge.

___. 2006. "Iraq 1990-2004 and the London Antiquities Market." In Archaeology, Cultural Heritage, and the Antiquities Trade, edited by Neil Brodie, Morag M. Kersel, Christina Luke and Kathryn Walker Tubb, 206-226. Gainesville: University Press of Florida.

_—_. 2008. “The Western Market in Iraqi Antiquities.” In Preventing Looting in Wartime: Learning from the Lessons of Iraq, edited by Lawrence Rothfield, 63-74. Walnut Creek: AltaMira.

___. 2009. “Consensual Relations? Academic Involvement in the Illegal Trade in Ancient Manuscripts." In Criminology and Archaeology: Studies in Looted Antiquities, edited by Simon Mackenzie and Penny Green, 41-58. Oxford: Hart. 
___ 2011. "Scholarship and Insurgency? The Study and Trade of Iraqi Antiquities". In Illicit Traffic of Cultural Objects: Law, Ethics, and the Realities. An Institute of Advanced Studies Workshop, 4-5 August. Perth: University of Western Australia, 2011, http://traffickingculture.org/publications/brodie-neil2011-scholarship-and-insurgency-the-study-and-trade-of-iraqi-antiquities-inillicit-traffic-of-cultural-objects-law-ethics-and-the-realities-an-institute-ofadvanced-studies-works/ (accessed 30 May 2015).

___. 2014. “The Antiquities Market: It's All in a Price." Heritage and Society 7: $32-46$.

Brodie, Neil and Daniel Contreras. 2012. "The Economics of the Looted Archaeological Site of Bâb edh-Dhrâ': A View from Google Earth.” In All The Kings Horses: Looting, Antiquities Trafficking and the Integrity of the Archaeological Record, edited by Paula K. Lazrus and Alex W. Barker, 9-24. Washington DC: Society for American Archaeology.

Brodie, Neil and Morag M. Kersel. 2014. “Wikileaks, Text and Archaeology: The Case of the Schøyen Incantation Bowls." In Archaeologies of Text, edited by Matthew T. Rutz and Morag M. Kersel, 198-213. Oxford: Oxbow.

Casana, Jesse and Mitra Panahipour. 2014. "Notes on a Disappearing Past: Satellite-Based Monitoring of Looting and Damage to Archaeological Sites in Syria." Journal of Eastern Mediterranean Archaeology and Heritage Studies 2: 128151. 
Chappell, Duncan and Kenneth Polk. 2011. "Unravelling the Cordata: Just How Organised is the International Traffic in Cultural Objects?" In Crime in the Art and Antiquities World: Illegal Trafficking in Cultural Property, edited by Stefano Manacorda and Duncan Chappell, 99-116. New York: Springer.

Contreras, Daniel and Neil Brodie. 2010. “Quantifying Destruction: An Evaluation of the Utility of Publicly-available Satellite Imagery for Investigating Looting of Archaeological Sites in Jordan." Journal of Field Archaeology 35: 101-114.

Cunliffe, Emma. 2012. Damage to the Soul: Syria's Cultural Heritage in Conflict. Palo Alto: Global Heritage Fund. http://ghn.globalheritagefund.com/uploads/documents/document 2107.pdf (accessed 26 September 2014).

Curtis, John, Hussein Raheed, Qais, Clarke, Hugo, Al Hamdani, Abdulamir, Stone, Elizabeth, van Ess, Margarete, Collins, Paul and Mehsin Ali. 2008. An Assessment of Archaeological Sites in June 2008: An Iraqi-British Project. London: British Museum.

http://www.britishmuseum.org/PDF/Iraq\%20Report with\%20images.pdf (accessed 16 October 2014).

DGAM 2014. Annual Report 2013. Damascus: Syrian Arab Republic, Directorate General of Antiquities and Museums, 
http://dgam.gov.sy/archive/docs/File/downloads/dgam report 2013 en.pdf (accessed 16 October 2014).

Fossey, John M. 2014. "Illicit Traffic in Antiquities: Some Canadian Experiences.” In Cultural Property Crime: An Overview and Analysis of Contemporary Perspectives and Trends, edited by Joris D. Kila and Marc Balcells, 206-220. Leiden: Brill.

Freeman, David J., MacDonald, Sally and Colin Renfrew. 2005. An Inquiry into the Provenance of 654 Aramaic Incantation Bowls Delivered into the Possession of UCL by, or on the Instruction of, Mr Martin Schøyen. London: University College London.

Gerstenblith, Patty. 2009. "Increasing Effectiveness of the Legal Regime for the Protection of the International Archaeological Heritage." In Cultural Heritage Issues: The Legacy of Conquest, Colonization, and Commerce, edited by James A.R. Nafziger and Ann M. Nicgorski, 305-324. Leiden: Martinus Nijhoff.

Gibson, McGuire. 2009. "Legal and Illegal Acquisition of Antiquities in Iraq, 19th Century to 2003." In Cultural Heritage Issues: The Legacy of Conquest, Colonization, and Commerce, edited by James A.R. Nafziger and Ann M. Nicgorski, 185-198. Leiden: Martinus Nijhoff. 
Grissman, Carla. 2006. “The Kabul Museum: In Turbulent Years.” In Art and Archaeology of Afghanistan: Its Fall and Survival, edited by Juliette van KriekenPieters, 61-78. Leiden: Brill, 2006.

Hanson, Kathryn. 2011. "Ancient Artifacts and Modern Conflict: A Case Study of Looting and Instability in Iraq." In Cultural Heritage, Ethics, and the Military, edited by Peter Stone, 113-128. Martlesham: Boydell and Brewer.

Hladik, Jan. 2013. “The UNESCO Conventions on the Protection of Cultural Property." In Culture and Development: Stop the Illicit Traffic of Cultural Property, edited by Herman van Hooff, 14-18. Havana: UNESCO.

Kersel, Morag M. and Meredith S. Chesson. 2013. “Looting Matters: Early Bronze Age Cemeteries of Jordan's Southeast Dead Sea Plain in the Past and Present." In Oxford Handbook of the Archaeology of Death and Burial, edited by Liv Nilsson Stutz and Sarah Tarlow, DOI: 10.1093/oxfordhb/9780199569069.013.0038. Oxford: Oxford University Press.

Lawler, Andrew. 2001. "Destruction in Mesopotamia." Science 293: 32-35.

Mackenzie, Simon. 2011. "The Market as Criminal and Criminals in the Market: Reducing Opportunities for Organized Crime in the International Antiquities Market." In Crime in the Art and Antiquities World: Illegal Trafficking in Cultural Property, edited by Stefano Manacorda and Duncan Chappell, 69-86. New York: Springer. 
——_. 2014. "Conditions for Guilt-free Consumption in a Transnational Criminal Market." European Journal on Criminal Policy and Research DOI 10.1007/s10610-013-9229-z.

Mackenzie, Simon and Tess Davis. 2014. "Temple Looting in Cambodia Anatomy of a Statue Trafficking Network." British Journal of Criminology 54: 722-740.

Mackenzie, Simon and Penny Green. 2009. “Criminalising the Market in Illicit Antiquities: An Evaluation of the Dealing in Cultural Objects (Offences) Act 2003 in England and Wales." In Criminology and Archaeology: Studies in Looted Antiquities, edited by Simon Mackenzie and Penny Green, 145-170. Oxford: Hart.

Manacorda, Stefano. 2011. “Criminal Law Protection of Cultural Heritage: An International Perspective." In Crime in the Art and Antiquities World: Illegal Trafficking in Cultural Property, edited by Stefano Manacorda and Duncan Chappell, 17-50. New York: Springer.

Peters, Gretchen. 2010. Crime and Insurgency in the Tribal Areas of Afghanistan and Pakistan. West Point: Combating Terrorism Center, https://www.ctc.usma.edu/posts/crime-and-insurgency-in-the-tribal-areas-ofafghanistan-and-pakistan (accessed 16 October 2014). 
Planche, Edouard. 2013. “The 1970 Convention.” In Culture and Development: Stop the Illicit Traffic of Cultural Property, edited by Herman van Hooff, 20-22. Havana: UNESCO.

Politis, Konstantinos. 2002. "Dealing with the Dealers and the Tomb Robbers: the Realities of the Archaeology of the Ghor es-Safi in Jordan." In Illicit Antiquities: The Theft of Culture and the Extinction of Archaeology, edited by Neil Brodie and Kathryn Walker Tubb, 257-267. London: Routledge.

Polk, Kenneth. 2009. "Whither Criminology in the Study of the Traffic in Illicit Antiquities?" In Criminology and Archaeology: Studies in Looted Antiquities, edited by Simon Mackenzie and Penny Green, 13-28. Oxford: Hart.

Prott, Lyndel. 2011. Strengths and Weaknesses of the 1970 Convention: An Evaluation 40 Years After its Adoption. Paris: UNESCO, http://www.unesco.org/new/fileadmin/MULTIMEDIA/FIELD/Brussels/pdf/str engths $\% 20$ and $\% 20$ weaknesses $\% 20$ of $\% 20$ the $1970 \% 20$ convention.pdf (accessed 17 October 2014).

Rose, Jerome C. and Dolores L. Burke. 2004. “Making Money from Buried Treasure." Culture Without Context, no. 14: 4-8.

Rothfield, Lawrence. 2009. The Rape of Mesopotamia: Behind the Looting of the Iraq Museum. Chicago: University of Chicago Press. 
Russell, John. 2008. “Efforts to Protect Archaeological Sites and Monuments in Iraq, 2003-2004." In Catastrophe! The Looting and Destruction of Iraq's Past, edited by Geoff Emberling and Katharyn Hanson, 29-44. Chicago: Oriental Institute of the University of Chicago.

Ulph, Janet and Ian Smith. 2012. The Illicit Trade in Art and Antiquities. Oxford: Hart.

Watson, Peter and Cecilia Todeschini. 2007. The Medici Conspiracy. New York: PublicAffairs.

Williams, Phil. 2009. Criminals, Militias, and Insurgents: Organized Crime in Iraq. Carlisle PA: Strategic Studies Institute, http://www.strategicstudiesinstitute.army.mil/pubs/display.cfm?pubID=930 (accessed 28 September 2014). 